hemisphere. The interesting fact emerges that the excess of temperature above the average for 1901-30 in the British Isles, which ranged from $1^{\circ}$ to $3^{\circ} \mathrm{F}$., was also experienced throughout Europe and the greater part of North America, the excess being more than $5^{\circ} \mathrm{F}$. over the north-east of Europe, most of Scandinavia and northern Canada and part at least of the Nile valley. The warmth of Europe and North America is seen to be associated with, if not due to, a lowering of mean pressure in the arctic regions and Siberia, combined with an excess of pressure over most of Europe, the United States and southern Canada. This information was available at the Meteorological Office within seven days of the conclusion of the month under review.

\section{Wear of Motor-Car Engine Cylinders}

THE problem of cylinder wear has now become very serious in commercial and public service vehicles, according to an article in the January issue of the Nickel Bulletin. This is due to the new designs giving higher efficiency, and also the use of aluminium pistons. Wear is considered to be due to a combination of two causes: mechanical abrasion and the corrosive attack of the cylinder walls by the products of combustion. The former predominates in vehicles running for long periods with a hot engine such as motor-buses used for long-distance runs in daily service. The latter effect is the more important for vehicles which run intermittently with long waits between runs, like delivery vehicles. In these the engines never get properly warm. The development of nickel cast iron has provided a satisfactory solution. The addition of one or two per cent of nickel to a suitable composition of base iron has produced cylinder castings which are readily machinable and yet have a high Brinell hardness. Recently the manufacturers of many commercial vehicles have obtained excellent results by using heavily alloyed iron. The cylinders of both petrol and Diesel vehicles are now being regularly made of irons containing 4-5 per cent of nickel with or without proportions of chromium and molybdenum. Improved machinability is obtained by slowly cooling the castings from a temperature of about $650^{\circ} \mathrm{C}$. When this course is followed, the original hardness is restored after machining by air-cooling the material from a temperature of about $850^{\circ} \mathrm{C}$. In France, this hard type of iron has been used for several years with satisfactory results for air-cooled motor-cycle cylinders.

\section{International Union of Biological Sciences}

Prof. M. J. Sirks (Wageningen, Netherlands), secretary of the above Union, reports that the next General Assembly will probably be held in July 1940 at Stockholm immediately before the seventh International Botanical Congress. The president is Prof. E. D. Merrill (Harvard) and the vice-president, Prof. D. M. S. Watson (London). The report in Nature $(136,612$; 1935) on the International Botanical Congress at Amsterdam in September 1935 referred to the establishment of a liaison between the Congress and the Union. Dr. F. Verdoorn (Leyden), secretary of the Botanical Section of the Union, reports on the work of this Section, which was deputed to execute the resolutions passed by the Congress and to assist the various commissions and committees then appointed. He reports that an index of current plant science periodicals, prepared by the Commission for Documentation, will be issued during 1937, and that the Commission for Urgent Taxonomic Needs is preparing an "Index Herbariorum". Suggestions or questions bearing on botanical nomenclature should be sent to Dr. T. A. Sprague, Royal Botanic Gardens, Kew, secretary of the Commission of Nomenclature.

\section{Scientific Annual Publications: New ASLIB List}

A sixteen-page booklet has been issued by the Association of Special Libraries and Information Bureaux as a supplement to the ASLIB Book List, eontaining classified particulars of 212 recommended annual publications of scientific and technical interest, published in the English language. The publications are arranged by subjects, and include representative U.S.A. publications as well as those of the League of Nations and many of H.M. Government reports, etc., which are not often found in Press guides. The list should be of considerable service to information officers and those in charge of reference libraries or intelligence departments. The List can be obtained from the Association of Special Libraries and Information Bureaux, 31 Museum Street, W.C.1, at a charge of $2 s$. per copy to subscribers to the ASLIB Book List and $3 s$. $6 d$. to non-subscribers.

\section{International Congress of Anthropological Sciences}

ARRANGEMENTS are now announced for the second International Congress of Anthropological and Ethnological Sciences to be held at Copenhagen on August 1-6, in accordance with the decision taken at the first congress in London in 1934. It will be under the patronage of H.M. the King of Denmark and Iceland. The Congress will meet in seven sections, covering respectively physical anthropology, psychology, demography, ethnology, ethnography in six sub-sections according to geographical areas, sociology and religion, and linguistics and writing. Arrangements have been made for exhibitions and demonstrations in connexion with the subjects to be discussed, among them anthropological material of the Eskimo and Scandinavians of Groenland in the Middle Ages, and from the prehistoric burials of Denmark, and the skulls of Lagoa Santa, Brazil. There will be a demonstration of the relation of the ancient dwellings of Denmark and the structural systems of prehistoric times, which will take place at the Lyngby Folk Museum, where there will also be an exhibition of Danish national dances, including those of the Faroe Islands. A collection will be on view of medieval Icelandic manuscripts referring to the discovery of Greenland and Vinland, as well as the manuscript of Pomo de Ayala on the Kingdom of the Incas and Peru, recently published by the Institut d'Ethnologie de Paris, and manuscripts of the Iranian Avesta. The Ethnographical Museum, which has been closed for several years for enlarge- 
ment and is the oldest in Europe, having been founded in 1846, will be reopened to the public for the first time at the meeting of the Congress. At the close of the session, an excursion will be made through Denmark, on which visits will be paid to kitchen. middens, Megalithic tombs, tumuli of the bronze age, iron age fortifications, the new Viking ship recently discovered at Ladby, and other antiquities of the Middle Ages. Subscriptions (members 30 Danish crowns, associates $15 \mathrm{Kr}$.) may be addressed to the Treasurer of the Congress, Nationalmuseet, $10 \mathrm{Ny}$ Vestergade, Copenhagen, $\mathrm{K}$.

\section{Seventeenth International Geological Congress}

THE seventeenth International Geological Congress is being held in Moscow on July 20-30, as noted in Nature of January 23, p. 143. Many tours for the delegates have been arranged ; for this purpose guidebooks have been prepared giving detailed descriptions of the routes, all the interesting outerops of mineral strata, the deposits of useful minerals, etc., with maps, plans and sectional drawings. Every delegate has a set of twenty-eight guide-books, and a newly issued geological map of the Soviet Union; each tour is being conducted by a Soviet geologist. According to a report issued by the Soviet Union Year Book Press Service, 403 foreign delegates, representing forty-six different countries, are attending the Congress; they include 139 from the United States, 50 from Great Britain, 33 from France, 20 from Japan and Manchukuo, 13 each from Germany and South Africa, and 11 from Sweden. Of Soviet geologists, 1,600 have intimated their desire to be present, but as many of them are at present engaged in field work, not all of them will be able to attend. The delegates will spend two days in Leningrad, where a session of the Congress will be held, and visits will be paid to the geological museums of the Mining Institute, the Central Institute of Scientific Research, the Arctic Institute, to give representatives of foreign countries an opportunity of becoming acquainted with the general characteristics of the mineral resources of the Soviet Union. In Moscow, the Congress will hold its sessions at the Observatory, where the institutes of the Academy of Sciences of the U.S.S.R. have also arranged an exhibition of collections relating to mineralogy, geochemistry and useful minerals; and the Palæontological Institute is showing its collection of Perm vertebrates of the North Dvina Gallery. Among the subjects coming up for discussion at the Congress are: problems of oil and world oil resources ; geology of coal deposits ; the Pre-Cambrian system and its useful minerals; the Perm system and its stratigraphical arrangement; the inter-connexion of tectonic processes, magmatic formations and ore deposits; tectonic and geochemical problems of Asia ; deposits of rare elements ; geophysical methods in geology; geology of the Arctic and Antarctic.

\section{Beit Fellowships for Scientific Research}

The Trustees have awarded Beit fellowships for scientific research, tenable at the Imperial College of
Science and Technology during the academic year 1937-38, as follows : extensions of fellowships already satisfactorily held for one year to Dr. N. Kemmer, for the continuation of his work on the theoretical studies in nuclear physics, under the direction of Prof. S. Chapman; and to E. K. Woodford, for the continuation of his research in plant physiology, the work to be done under the supervision of Prof. F. G. Gregory ; new fellowships tenable for one year, but renewable for a second, to $\mathrm{D}$. W. Goodall, for research on the physiology of the tomato plant, under the direction of Prof. F. G. Gregory ; H. A. C. McKay, for an investigation of chemical problems by the radioactive indicator method, under the direction of Prof. J. C. Philip; A. K. Powell, for research on the various strains of Heterodera Schachtii, under the direction of Prof. J. W. Munro. The Trustees have also awarded a special Beit research scholarship to Dr. A. G. Gaydon, for research in spectroscopy under the direction of Prof. G. P. Thomson.

\section{Announcements}

Geheimrat Prof. Erich Lexer, professor of surgery in the University of Munich, and the chief representative of plastic surgery in Germany, has been awarded the Goethe Medal for art and science on the occasion of his seventieth birthday.

THE sixth International Montessori Congress will be held in Copenhagen under the auspices of the Danish Minister of Education on August 1-10. Dr. Maria Montessori will give an address entitled "Educate for Peace". Further information can be obtained from the General Director, International Montessori Association, 1 Hampstead Hill Gardens, London, N.W.3.

Accordrng to official reports, the birth-rate in Soviet Russia is steadily increasing. Last January, the number of births registered was $21 \cdot 7$ per cent higher than in January 1936, and in the first quarter of this year it was about 30 per cent higher than in the corresponding quarter of 1936. Of the Union republies the Ukraine records the largest increase for the quarter, namely, 70 per cent.

The University of Reading proposes to reprint, in type similar to that of the original and accompanied by wood-cuts of the original drawings, the "Observa. tories Anatomicæ Selectiores Amstelodamensium", 1667-73. This work, the record of the observations of the Amsterdam School on the anatomy of seven mammals, four birds, the tortoise, the frog and thir. teen fishes, is rare and its contents not widely known among biologists. Prof. F. J. Cole, to whom subscriptions for copies ( 1 guinea each) should be sent, is contributing a critical introduction.

Erratum.-In the announcement in Nature of July 17, p. 104, of the award of the Johannes Schmidt Medal to Mr. H. G. Maurice the words 'thirteenth annual meeting' should have been 'thirtieth annual meeting'. 